CHAPTER 5

\title{
A Striking Anticipation of Lavoisier's Theory
}

THAT Lavoisier's epoch-making experiments of the autumn of $\mathbf{1 7 7 2}$ were in large measure a consequence of the convergent influences upon him of Stephen Hales and Guyton de Morveau seems highly probable from the evidence already set forth. This conclusion gains strong, if indirect, support from the remarkable fact that another contemporary Frenchman independently set down an identical conclusion, nearly a year before Lavoisier, about the role of air in calcination; and though he may have hit upon the idea even earlier, he was stimulated to formulate it fully and clearly by the same influences. A striking anticipation of Lavoisier's hypothesis-an anticipation which, though he did not confirm it by experiment, is closer to Lavoisier's idea than the much-cited speculations of Jean Rey and Père Béraut ${ }^{1}$-must be

${ }^{1}$ As already pointed out, Rey believed that particles of air, rendered adhesive by heat, combined with the calx but did not produce it; and Béraut, like Du Clos, thought that impurities in the air were responsible. See the detailed summary of Béraut's views by McKie, "Béraut's Theory of Calcination," loc. cit., pp. 284-289. 


\section{A STRIKING ANTICIPATION}

credited to an unexpected person: Anne Robert Jacques Turgot (1721-1781), the distinguished philosophe, economist, and French public servant. A man of wide-ranging interests, an enthusiastic amateur of science who had studied chemistry under Lavoisier's teacher, G. F. Rouelle, Turgot in 1771 was intendant, or chief officer of the Crown, for the generality of Limoges. ${ }^{2}$ Despite the pressure of his duties he found time to carry on a chatty, philosophical correspondence, touching on all manner of timely questions, with the young Marquis de Condorcet, the gifted mathematician of the Academy of Sciences. The correspondence is particularly full and interesting for the years that especially concern us here, i.e., 1771$1773 .^{3}$ Condorcet seems to have taken it upon himself to keep Turgot abreast of doings in the capital; and although many of his letters are filled with personal and literary gossip, there are a number devoted to scientific

${ }^{2}$ Turgot's scientific interests are treated lightly by his biographers. For the scientific side of his association with his friend Madame d'Enville (1716-1794) and her son, the Duc de la Rochefoucauld d'Enville (1743-1792), there is some information in Emile Rousse, La Roche-Guyon, châtelains, château et bourg (Paris, 1892). Turgot's most significant scientific publication is his long and interesting article "Expansibilité" in the Encyclopédie (VI [1756], 274-285). See his extensive corrections and additions in the errata (VII [1757], 1028-1029). In 1775 Lavoisier referred to this article as "rempli des vues les plus vastes \& les plus neuves, \& qui porte par-tout l'empreinte du génie" (Observations sur la physique, 5 [1775], 429). This was probably a gesture of ingratiation rather than a scientific judgment on Lavoisier's part, for when he wrote in the spring of 1775 Turgot was Controller-General of Finance and had just organized the Régie des poudres to which he appointed Lavoisier in June.

${ }^{3}$ Henry, Correspondance inédite de Condorcet et de Turgot, pp. 33-156. 


\section{LAVOISIER-THE CRUCIAL YEAR}

topics. The first reference to our subject is in a letter of Condorcet dated August 2, 1771:

Nous avons à l'Académie un excellent mémoire de chimie qui nous vient d'un conseiller au Parlement de Dijon. Il a pour objet l'augmentation du poids réel des métaux par la calcination. Il a fait sur ce sujet beaucoup de nouvelles expériences, et il prétend que le Phlogistique n'est pas attiré par chaque molécule de matière terrestre comme les autres corps et quau contraire il est animé de forces qui lui donnent une direction contraire à celle de la pesanteur. ${ }^{4}$

Fortunately, Turgot's long and detailed reply-dated Limoges, August 16,1771-has been preserved. It is an extraordinarily interesting letter, which, if echoes of it ever came to Lavoisier's ears, would surely earn Turgot something more than a footnote in a history of the Chemical Revolution. To be appreciated it should be read in its entirety; I shall only summarize it with a few key excerpts.

Turgot finds Guyton's explanation of the augmentation effect-as somewhat misrepresented by Condorcet, who had not yet read the work-to be wholly absurd, and he writes:

Je ne conçois pas comment les chimistes n'ont pas encore pensé à expliquer le phénomène en question par une cause qui se présente d'elle-même et que j’aurais publiée il y a bien long temps si j’avais le loisir de faire des expériences. Cependant je la crois prouvée par un assez grand nombre d'inductions pour etre très-persuadé que c'est la vraie.

${ }^{4}$ Ibid., p. 58. 


\section{A STRIKING ANTICIPATION}

After arguing that something must be added to the metal if its weight is increased and after dismissing the possibility that light might be responsible, he continues:

Puisque la lumière ne peut augmenter le poids du métal calciné, il faut donc voir s'il n'y a pas dans le voisinage du métal quelqu'autre matière qui puisse s'y unir pendant le cours de l'opération.

This substance can only be air, which possesses weight, is abundantly available, and is known to combine with other principles of bodies to produce many different compounds (mixtes):

Il est certain par une foule d'expériences, et en particulier par celles de Stales [sic], que cet air combiné entre dans la composition des corps les plus durs et contribue à leur liaison et à leur dureté, ainsi que l'eau fait la liaison et la dureté des marbres, ainsi que le phlogistique fait la liaison des métaux.

Air combines or is given off in different chemical operations depending upon whether its affinity for the substance with which it is combined is greater or smaller than for other substances to which it is exposed. Effervescences encountered in familiar chemical reactions are produced by bubbles of air released from combination. Since air can combine with bodies

et puisqu'il n'y a que de l'air à la portée du métal qui se calcine, il faut bien en conclure que l'augmentation de poids survenue à ce métal est due à l'air qui, dans l'opération de la combustion, s'est uni à la terre métallique et a pris la place 
du Phlogistique qui s'est brûlé et qui sans être léger d'une légèreté absolue est incomparablement moins pesant que l'air, apparemment parce qu'il contient moins de matière. ${ }^{5}$

It is really surprising that this letter, with its remarkable anticipation of Lavoisier's own explanation and its reference to "Stales" (which should evidently be read as "Hales," not, as a later editor believed, as "Stahl"), should have escaped notice. ${ }^{6}$ Here, with much greater precision and clarity than Jean Rey, Du Clos, or Père Béraut-none of whom, in any event, he had reason to have readTurgot suggests that calcined metals increase in weight by a combination with air. That Turgot, unlike Rey and

5 Ibid., pp. 59-62. This letter, with others of Turgot to Condorcet from this correspondence, can also be found in Gustave Schelle, Oeuvres de Turgot et documents le concernant (Paris, 1913-1923), III, 542-547.

${ }^{6}$ In reproducing this passage from Charles Henry's version, Schelle changed the reading from "Stales" to "Stahl." Perhaps Turgot had written "S. Hales," for it makes little sense to attribute to Stahl (who firmly denied the chemical role of air) experiments on the combination of air with bodies. But perhaps Turgot was originally at fault; elsewhere he writes: "Ces messieurs [Venel and Macquer] avaient rappelé à une meilleure théorie et ils avaient étendu les conséquences des premières expériences de Stahl, lequel est vraiment le premier qui ait aperçu le rôle que l'air joue dans la nature comme principe des mixtes; mais toutes les idées spéculatives de Stahl, toutes les conséquences qu'il tire des faits qu'il a vus sont infiniment embrouillés et manquent de cette dialectique, de cette précision d'idées et de langage dont jusqu'ici les physiciens se sont occupés beaucoup trop peu" (letter of November 27, 1772, ibid., p. 111). This reference to the style of Stahl suggests a genuine confusion. Rhoda Rappaport believes that Turgot, as a pupil of Rouelle, is reflecting the Stahlianism of his teacher, which, as she has pointed out, was combined with the teachings of Hales. The two names were sometimes confused by Rouelle's auditors. 


\section{A STRIKING ANTICIPATION}

Béraut, was thinking of a definite chemical reaction, is evident from the following sentence:

Le magasin qui fournit à cette augmentation ne manquera pas puisque l'atmosphère fournit toujours de l'air à mesure que la terre métallique en absorbe. Cette absorption a ses limites ou son point de saturation comme toute les unions chimiques et c'est cette saturation qui établit le rapport de l'augmentation du poids dans les differents métaux calcinés.

Then, soon after, comes the most striking passage in this truly remarkable letter:

Au surplus, cette calcination des métaux devrait être appelée combustion; ce n'est qu'une branche du grand phénomène de la combustion par lequel le phlogistique uni aux principes terreux s'en dégage à un degré de chaleur constant dans chaque corps, mais vraisemblablement variable dans les différents corps à raison de la force de l'union. . . .

Il suit de là que le phénomène de l'augmentation du poids devrait être général dans la combustion de tous les corps; je voudrais constater cette conséquence par des expériences. ... Mais le temps me manque et javoue que sans nouvelles expériences les inductions tirées de celles qui sont déjà faites me paraissent donner à cette théorie une probabilité fort approchante de la certitude. ${ }^{8}$

Condorcet commented favorably on Turgot's theory in a letter of September 10, 1771, expressing approval of his

${ }^{7}$ Correspondence inédite, p. 62.

8 Ibid., pp. 62-63. As an experimental test of his theory, Turgot suggests treating calxes (cendres métalliques) with acids, to see if more air is driven off than when the pure metal is similarly dissolved. The result would certainly have confused him, but he did not perform the experiments. 
correspondent's suggestion and remarking that "il faudrait qu'un chimiste suivît votre explication et imaginât des expériences décisives pour ou contre. C'est une des questions les plus importantes qu'on puisse agiter dans cette science." ${ }^{9}$ But it was not until July, 1772, that Condorcet wrote that he had finally read Guyton's essay, almost certainly as printed in the Digressions ${ }^{10}$ which had just appeared a month earlier. Though the subject is discussed in later letters exchanged between Turgot and Condorcet in the autumn of 1772 , we need not follow the correspondence further, for by now Lavoisier had moved to the center of the stage and was hard at work, determinedly, albeit quietly.

One question forces itself upon us: did Condorcet, not always the most discreet or reticent of men, disclose to his colleague, Lavoisier, the theory that Turgot had advanced in the letter of August 16, 1771? It is impossible to tell, but I rather think-from a remark in a letter of Condorcet to Turgot-that he did not. On December 5, 1772, Condorcet asked Turgot whether he should mention the latter's conjectures in a eulogy of the chemist Du Clos which he was preparing, especially if Turgot did not expect to perform the necessary experiments in the near future. ${ }^{11}$

${ }^{9}$ Ibid., pp. 69-71.

${ }^{10}$ Ibid., pp. 93-95. "J'ai lu l'ouvrage de M. de Morvaux [sic] sur le phlogistique, je n'en suis pas mécontent; mais il est au-dessous de ce que jen espérais." The fact that he also writes that he has read Guyton "sur la dissolution et les cristallisations" makes it clear that Condorcet had been reading the printed Digressions, which includes an essay on this subject.

${ }^{11}$ Ibid., pp. 117-118. Condorcet is here referring to his Histoire de l'Académie ou des académiciens morts avant 1699, published early in 1773 and reviewed in the April 15 issue of the Journal encyclopédique, pp. 248-259. Condorcet undertook this project 


\section{A STRIKING ANTICIPATION}

This seems to imply that Condorcet had been discreetly silent about his friend's disclosure, though he may have made a distinction between publishing Turgot's theory and confiding it, or hinting at it, by word of mouth. Yet Condorcet could hardly have kept the matter wholly to himself, for we find him writing to Turgot, late in November, that he and a chemist of the Academy, B. G. Sage, were about to collaborate on an experiment, which we have described above, to see if fixed air is produced when a metallic calx is reduced. ${ }^{12}$ Condorcet could hardly have failed to discuss with Sage the significance of this experiment in the light of Turgot's conjecture, if indeed it was not Turgot's letter that suggested it; but there is no evidence that he mentioned the matter to Lavoisier. It is evident, at least, that Lavoisier, who had deposited

to advance his ambitions to succeed Grandjean de Fouchy, the aged and ineffectual Perpetual Secretary of the Academy of Sciences. In April, 1773, Condorcet won out in a bitterly contested election over the astronomer, Jean-Sylvain Bailly, the candidate backed by Buffon, and was named "secrétaire perpétuel en survivance." For an account of this event see Jean Nourrisson, Trois révolutionnaires, Turgot, Necker, Bailly (Paris, 1885), pp. 46 and $338-340$.

${ }^{12}$ Correspondance inédite, p. 108. For the projected experiment of Sage and Condorcet see above, pp. 109-110. On November 22, 1772, Turgot wrote disparagingly (ibid., pp. 111-112) of the French having adopted "des Ecossais cette fausse et impropre dénomination d'air fixe," and expressed irritation that the "Ecossais" claimed to have discovered "ce que nous savions il y a plus de vingt ans." This reference to the "Ecossais" makes it evident that Turgot had by this time seen the recent issues of Rozier's journal. But in a note he speaks of having read the review of Priestley's Directions which had just appeared in the September Monthly Review (47 [1772], 227-230). Here we find a summary of the achievements of Hales, Brownrigg, MacBride, Cavendish, and Lane, but no mention of Black. 
the famous sealed note only a month before, had not disclosed to Condorcet or Sage the secret of his first epochmaking experiments on combustion.

By resurrecting Turgot's unpublished conjectures and calling attention to his anticipation by a full year of Lavoisier's theory of the chemical role of air in calcination, I certainly do not wish to diminish the credit or tarnish the laurels the great French chemist has richly earned as one of the chief founders of modern chemistry. And I am reluctant to believe that Lavoisier was set on the path of his reform of chemistry by an indiscreet revelation on the part of Condorcet. There are instances enough in Lavoisier's career which have led scholars to question his generosity and that "delicatesse en Litterature et en Physique" he once spoke of, in a letter to Rozier, as essential in science. ${ }^{13}$ We can dispense with another.

Despite some resemblances in the details of their theories, ${ }^{14}$ I prefer to think we are confronted with an extraordinarily clear-cut example of parallel thinking where two contemporaries, exposed to the same influences and meditating on the same phenomenon, came to an identical conclusion. Both men were familiar with Hales's doctrine of fixed air, though they knew little or nothing of the more recent work done in Britain; both interpreted effer-

13 Oeuvres de Lavoisier-Correspondance, II, 465.

14 There is a vague similarity between the theory Lavoisier sets forth in his "Système sur les élémens" and the remark in Turgot's letter of August 16, 1771, where air, water, and phlogiston are compared as binding agents when fixed in bodies. One could perhaps point to Turgot's suggestion (cf. note 8 above) that calxes might be treated with acid to see if more air is given off than by the corresponding pure metal. This problem was later raised by Lavoisier in the August memorandum. 


\section{A STRIKING ANTICIPATION}

vescences as the release of combined air; and to each of them an application of these facts came to mind when they speculated on calcination and reduction and learned of Guyton's experiments on the increased weight of calcined metals. To both men-alike anxious to see chemistry develop in the quantitative spirit of "la saine physique"the combination of air with a metal was a more likely explanation of the augmentation effect than those fancies of Guyton which violated the accepted principles of Newtonian physics. What Turgot's letter does for us is to make explicit the principal influences we rather laboriously deduced as having shaped Lavoisier's thought and determined its direction. 